DOI: 10.35757/RPN.2016.24.01

Piotr Andrzejewski

\title{
WIEDEŃ NIE MOŻE BYĆ JAK CHICAGO. NEOLIBERALIZM I RZĄDY WOLFGANGA SCHÜSSELA W AUSTRII W LATACH 2000-2006
}

\section{Wstęp}

Czwartego lutego 2000 roku w Austrii doszło do przełomu. Przez najbliższe siedem lat alpejską republiką miała rządzić prawicowa koalicja Partii Ludowej (ÖVP) i Partii Wolności (FPÖ) (zwana także od partyjnych kolorów niebiesko-czarną). Socjaldemokraci stracili swojego kanclerza pierwszy raz od trzydziestu lat, a tzw. wielka „czarno-czerwona" koalicja socjalistów i ludowców, która formalnie lub nieformalnie rządziła Austrią od końca II wojny światowej, przestała istnieć. Obejmujący wtedy urząd kanclerz Wolfgang Schüssel miał zostać nazwany później: Der Wendekanzler, kanclerzem przełomu. Jaki był to przełom? Według jednego z prominentnych austriackich politologów, Emmmericha Talosa: był to przełom polegający na gruntownej zmianie paradygmatów rządzących austriacką polityką, zmianie w stronę neoliberalizmu i konserwatyzmu1. Czy ta opinia jest uprawniona? By odpowiedzieć na to pytanie, należy przedstawić ideowe podstawy neoliberalizmu oraz jego austriackiej odmiany oraz podsumować siedem

1 E. Talos, Der österreischische Wohlfahrtsstaat: Entwicklung und Herausforderungen, Wiedeń 2001, s. 2, http://www.demokratiezentrum.org/fileadmin/media/pdf/wohlfahrtsstaat.pdf (dostęp: 3 marca 2016). 
lat neoliberalnych rządów Wolfganga Schüssela. Ocena tych rządów będzie umieszczona w szerszym kontekście austriackiej polityki. Takie podejście pozwoli gruntownie ocenić wpływ neoliberalizmu na politykę prowadzoną $\mathrm{w}$ alpejskiej republice.

\section{Czym jest neoliberalizm?}

Encyklopedia Britannica definiuje neoliberalizm jako ideologię i model polityczny, który kładzie szczególny nacisk na znaczenie wolnego rynku i konkurencji. Podkreśla jednak, że ścisła definicja neoliberalizmu jest przedmiotem debaty. Podstawy neoliberalizmu, co do których istnieje zgoda, to: leseferyzm oraz pogląd, że rozwój gospodarczy przyczynia się do postępu ludzkości. Wolny rynek ma być najlepszym i najefektywniejszym sposobem alokowania surowców, w przeciwieństwie do interwencjonizmu państwowego, który miałby być o wiele mniej wydolny. Konsekwencją takiego poglądu jest stwierdzenie potrzeby zmniejszenia inwestycji i regulacji państwa w gospodarkę oraz jej uwolnienie poprzez prywatyzację i deregulację.

Po kryzysie finansowym z roku 2008 neoliberalizm coraz częściej przedstawiany jest $\mathrm{w}$ negatywnym świetle. Łączy się on $\mathrm{z}$ pejoratywnymi pojęciami, takimi jak „rynkowy fundamentalizm”, czyli pogląd quasi-religijny, nieracjonalny, polegający na radykalnej wierze w sprawność wolnego rynku. Zwolennicy neoliberalizmu przedstawiani są jako wyznawcy. Jako ciekawostkę i komentarz można podać słowa słynnego Austriaka Arnolda Schwarzeneggera, który twierdził, że Milton Friedman i jego program popularyzujący neoliberalne idee Free to Choose, był dla niego objawieniem, które zmieniło jego życie. Aktor i polityk mówił: „,...] Przybyłem do Ameryki z socjalistycznego kraju, gdzie rząd kontroluje gospodarkę. Przybyłem do Ameryki i dostrzegłem, że im więcej rząd interweniował, przeszkadzał i wchodził w wolny rynek, tym gorzej radzi sobie państwo. Gdy tylko rząd wycofywał się z gospodarki, system wolnych przedsiębiorstw rósł, a nam żyło się lepiej i gospodarka wzrastała. Gdy przełączając programy w telewizji natknąłem się na Free to Choose, prowadzone przez zdobywcę Nagrody Nobla dr. Miltona Friedmana, po prostu zwaliło mnie z nóg. Dr Friedman 
wyraził, potwierdził i wyjaśnił wszystko co kiedykolwiek zaobserwowałem lub doświadczyłem, o tym jak działa gospodarka". Taki pozytywny komentarz mógł powstać w latach dziewięćdziesiątych XX wieku, jednak już dekadę później neoliberalizm nazywano „gospodarka, która czyni biedę"3.

Neoliberalizm stanowi ideowy odłam klasycznego liberalizmu, który wykształcił się pod wpływem myśli austriackiego filozofa i ekonomisty Friedricha von Hayeka. Myśl Austriaka miała przemożny wpływ na utworzenie się grupy chicagowskiej szkoły ekonomicznej, w skład której wchodzili i wchodzą tacy ekonomiści jak Frank Knight, Henry Simons, Milton Friedman czy Georg Stigler. Ich idee wprowadzono po raz pierwszy w życie w Chile podczas dyktatury Augusta Pinocheta. Przedstawiciele chicagowskiej szkoły ekonomicznej pojechali do Chile w charakterze doradców, a liczni chilijscy studenci udali się na staże i studia do University of Chicago. Grupę tych doradców nazywano w amerykańskiej prasie "Chicago Boys". Relatywny sukces gospodarczy Chile spowodował przyjęcie neoliberalnych strategii w Zjednoczonym Królestwie, Stanach Zjednoczonych i Australii. Po upadku żelaznej kurtyny neoliberalizm stał się również podstawą gospodarczej transformacji w krajach Europy Środkowo-Wschodniej. Podczas drugiej fali neoliberalizmu, jak nazywa ją Philipp Ther, neoliberalną politykę zaczęto prowadzić w krajach europejskiego południa: Włoszech, Hiszpanii i Grecji ${ }^{4}$. W tym czasie neoliberalizm trafia też do Austrii. Paradoksalnie, kraj, z którego wyszła idea neoliberalizmu, był jednym z ostatnich, który znalazł się pod wpływem tej idei.

Człowiekiem, który miał przeszczepić tę zrodzoną w Austrii ideę z powrotem na austriacki grunt, miał zostać Wolfgang Schüssel. W 1999 roku, zanim jeszcze został kanclerzem i uformował swój pierwszy rząd,

2 Ten interesujący wstęp w wykonaniu Arnolda Schwarzeneggera do programu Free to Choose, jest dostępny powszechnie w internecie. Na przykład https://www.youtube.com/watch?v=KKbHA76-Hi0 (dostęp: 12 lutego 2016). Komentarz w podobnym tonie wygłosił Paul Krugman: „Jeśli Keynes był Lutrem, to Friedman był Ignacym Loyolą założycielem Jezuitów. Naśladowcy Friedmana działali jak rodzaj zdyscyplinowanej armii wiernych, szerząc odwrót od keynsowskiej herezji".

${ }^{3} \mathrm{H}$. Afheld, Wirtschaft, die arm macht - vom Sozialstaat zur gespaltenen Geselschaft, Verlag Antje Kunstman GMBH, Monachium 2003.

4 P. Ther, Neue Ordnug auf dem alten Kontinent, Suhrkamp, Berlin 2014. 
Schüssel wydał książkę In Namen der Zukunft, w której zawarł swoje koncepcje i projekty dla Austrii na XXI wiek. W książce tej wypowiada się na praktycznie każdy możliwy temat od roli polityka w społeczeństwie, przez gospodarkę, kulturę, sytuację na Bałkanach, rozwój dzieci itd. Rozdziały są bardzo krótkie, niejednokrotnie zajmują ledwie pół strony. Książka ma zatem charakter manifestu osobistych poglądów przyszłego kanclerza. Wolfgang Schüssel przedstawia swoje propozycje dla austriackiej gospodarki, opierając się na silnym neoliberalnym paradygmacie.

Mehr privat - weniger Staat, mniej państwa, więcej prywatnego w Austrii, to główne hasło towarzyszące rozważaniom przyszłego kanclerza. Podając przykład zniesienia monopolu telekomunikacyjnego w Austrii, polityk zauważa $40 \%$ obniżkę cen i kosztów dla klientów i stawia prywatyzację innych sektorów gospodarki jako przykład na szybki rozwój. Podaje przykłady prywatyzacji przeprowadzonych przez rząd Margaret Thatcher w Zjednoczonym Królestwie jako historię sukcesu (Erfolgsstory). Całkowicie pomija masowe prywatyzacje $\mathrm{w}$ regionie Europy Środkowo-Wschodniej i patologie, jakie im towarzyszyły. Jednocześnie przewodniczący partii ludowej postuluje zachowanie tzw. złotej akcji, czyli pakietu większościowego w strategicznych dla państwa sektorach i przedsiębiorstwach. W innym miejscu stwierdza, że nie chodzi mu o prywatyzację za wszelką cenę. Chcąc odchudzić państwo i odciążyć je od licznych zadań, stwierdza jednak, że w miejscach, gdzie „ręka publiczna" dobrze wykonuje swoje obowiązki i dba o to, by być zorientowana na konsumentów (odbiorców usług państwa), można zezwolić na państwową własność i państwową działalność.

Jak osiagga się sukces gospodarczy? Tylko i wyłącznie podejmując ryzyko. Jednak, żeby móc je podjąć, należy funkcjonować w wolnej od regulacji gospodarce. W rynkowej konkurencji Schüssel dostrzega szansę na rozwój. Ukryty potencjał drzemiący w przedsiębiorcach należy uwolnić i nie mieć strachu przed konkurencją (keine Angst von Wettbewerb).

Samodzielność jednostek w życiu gospodarczym (ale też i prywatnym) ma być stanem idealnym, do którego należy dążyć. Aby osiągnąć ten idealny stan, należy ułatwić rozpoczęcie działalności gospodarczej (zwłaszcza wśród młodych przedsiębiorców). Podejmując ryzyko i działając darwinowską metodą prób i błędów, można osiągnąć o wiele 
lepsze wyniki gospodarcze niż w zastałej gospodarce państwa dobrobytu. Autor dostrzega też szansę w konkurencji nie tylko pomiędzy jednostkami i przedsiębiorstwami, ale również na poziomie regionów. Dużej szansy na rozwój upatruje on w jednoczącej się Europie i rozszerzeniu się Unii Europejskiej na wschód. Przewagę Austrii w tym wyścigu konkurencyjności ma dać ukierunkowanie na innowacje i rozwój technologiczny.

Logiczną konsekwencją większej konkurencji na rynku ma być zwiększona wydajność. Ma ona dotyczyć nie tylko wolnego rynku, ale też działań państwa. Austriacki kanclerz przywołuje w tym kontekście zasady New Public Management stosowane np. w Nowej Zelandii. Podstawą New Public Management jest stwierdzenie, że metody zarządzania, które sprawdziły się w firmach, korporacjach czy innych bytach prywatnych, mogą również, a nawet powinny zostać zastosowane w instytucjach państwowych. Wraz z New Public Management mają kroczyć takie zjawiska jak modernizacja czy urynkowienie (Vermarktlichung) administracji państwa. W ten sposób państwo będzie bardziej odpowiedzialne przed swoimi klientami, czyli obywatelami. Celem austriackiego polityka jest osiągnięcie „chudego państwa z wydajną administracją". Chcąc osadzić swój wywód w rzeczywistości, Schüssel podaje przykłady kolejek w urzędach i braku kolejek w bankach, które zautomatyzowały wiele swoich usług (np. wprowadzając bankomaty). Dodatkowo postulowana jest zmiana stosunków gospodarczych w rolnictwie, tak by przekształcić gospodarstwa rolników na utrzymaniu państwa w małe, rodzinne przedsiębiorstwa.

Całość wywodu zamyka skrótowa lista celów Austrii do osiągnięcia w XXI wieku. Są to: porządna polityka budżetowa (zwłaszcza ograniczenie zadłużenia), rozwój samodzielności jako podstawy nowoczesnej gospodarki, stworzenie państwa przedsiębiorstwa (Unternehmenstaat), prywatyzacja i deregulacja, tworzenie innowacji w otoczeniu przyjaznym nowoczesnym technologiom, likwidacja pracy na czarno, stworzenie wydajnego państwa socjalnego i osiągniecie wysokich standardów w nauce, aby móc wygrać konkurencję pomiędzy krajami.

Podsumowując należy zauważyć, że Wolfgang Schüssel daje się ponieść duchowi swoich czasów. Uwierzył on w koniec historii i triumf 
liberalnej demokracji, ze szczególnym naciskiem na słowo „liberalnej”. Pragnie on wprowadzić rynkowe relacje w każdej dziedzinie życia i stworzyć nowe i nowoczesne społeczeństwo. Sam pisze, że nadszedł nowy Grunderzeit, nowy czas założycieli. Tym określeniem nazywa się okres drugiej połowy XIX wieku, który jest widziany jako czas wielkiego boomu gospodarczego, szybkich przemian, rozwoju i industrializacji. Jako ciekawostkę można podać fakt, że pierwszy Grunderzeit zakończył się wraz z kryzysem gospodarczym w 1873 roku zapoczątkowanym przez załamanie na wiedeńskiej giełdzie. Kolejny czas nowych założycieli skończył się w podobny sposób jak pierwszy - kryzysem finansowym z roku 2008, rok po upadku drugiego rządu Wolfganga Schüssela.

Jednakże obraz ideowych podstaw neoliberalizmu w Austrii byłby niepełny bez przedstawienia programów i pomysłów na rządzenie prawicowo-populistycznego koalicjanta ÖVP, czyli Wolnościowej Partii Austrii pod przewodnictwem Jörga Haidera. Jest to o tyle ważne, że w koalicyjnym rządzie FPÖ objęła austriackie Ministerstwo Finansów.

Program FPÖ, partii populistycznej, nie jest tak jasny i klarowny jak w przypadku ÖVP. Podstawą ideową FPÖ jest wolność, rozumiana także jako wolność gospodarcza: wolność do prowadzenia działalności gospodarczej z jak najmniejszym wpływem państwa. Wolność oznacza możliwość podejmowania decyzji, ale również branie za te decyzje osobistej odpowiedzialności. Dotyczy to zwłaszcza relacji gospodarczych i konkurencji. FPÖ proponowała także zmiany i reformy w neoliberalnym duchu: prywatyzacja systemu emerytalnego, odciążenie gospodar$\mathrm{ki}$, rozmontowanie systemu polityki socjalnej i wprowadzenie niskiego podatku linowego ${ }^{5}$. Wpływ Miltona Friedmana na przewodniczącego FPÖ, Jörga Haidera, jest najlepiej dostrzegalny w jego książkach. Free to Choose Friedmana po niemiecku została wydana jako Chancen, die ich meine, który to tytuł Haider sparafrazował w swej książce: Freiheit, die ich meine. Neoliberalne idee i pomysły są $\mathrm{w}$ tej książce przemieszane z wspólnotowymi (narodowymi w swym charakterze) przedsięwzięcia-

5 H. Auer, Neoliberalismus unter Schwarz-Blau/Orange. Hochschulpolitik, Gesundheitspolitik und Wirtschaftspolitik der OVP-FPO/BZO Regierung auf dem Prufstand, Universität Wien, Wien 2008, s. 100. 
mi. Haider chce np. pomóc matkom w posyłaniu dzieci do przedszkoli, ale na neoliberalną modłę, w postaci bonu przedszkolnego. Jak mantrę również powtarza hasła o obniżce podatków, która automatycznie przyczyni się do powstania nowych miejsc pracy. Praca, a nie pomoc socjalna, jest podstawą funkcjonowania robotników. Do takiej mieszanki Haider dorzuca również antyestablishmentowe tony. Pragnąć więcej wolności i więcej liberalizmu, jednocześnie krytykuje skostniałe instytucje państwa i skostniały system podatkowy. Rozwalenie tego skostniałego systemu może najszybciej i najefektywniej nastąpić dzięki prywatyzacji i przeniesieniu obowiązków niewydajnego państwa w sferę prywatną. Karl Heinz Gasse, minister finansów, projektując swój budżet mówił: „potrzeba (jest) odchudzonego państwa, które może pomagać obywatelom poprzez mniej zakazów i nakazów, a więcej wolności. Oznacza to więcej jednostkowej odpowiedzialności”. Gasser jawi się jako radykalny zwolennik wolnego rynku. Uważa, że należy zbudować nowe państwo, państwo, które nie będzie działać tam, gdzie z powodzeniem działa rynek ${ }^{6}$. Jednak nawet on przyznaje, że są dziedziny funkcjonowania państwa, w które rynek nie powinien ingerować i wymienia politykę społeczna, służbę zdrowia oraz politykę ochrony środowiska. Należy je traktować jak dobro narodowe, które podlega ochronie. Różnice pomiędzy radykalnym liberalizmem a wspólnotowymi ideami opartymi w myśleniu o narodzie (obywatelach austriackich) wywołują ideowe napięcie i tarcia w FPÖ i uniemożliwiają stworzenie spójnego programu ${ }^{7}$.

Znając ideologiczne podstawy obu partii, które rządziły $\mathrm{w}$ latach 2000-2006, można skonfrontować te idee z praktyką rządzenia. Czy udało im się wprowadzić neoliberalną utopię w życie?

\section{Przed przełomem}

Austriacki kanclerz oraz jego koalicjanci dali się poznać jako przykładowi neoliberałowie. Czy wyznawane przez nich idee miały

6 Ibidem. s. 102.

7 Zob. P. Andrzejewski, Paradoks narodowego liberalizmu. Historia i idee Freiheitliche Partei Österreichs, „,Rocznik Polsko-Niemiecki” 2014, nr 22. 
przełożenie na politykę, którą prowadził w latach 2000-2006? By odpowiedzieć na to pytanie, należy najpierw przedstawić sytuację polityczno-gospodarczą Austrii przed „neoliberalnym przełomem”. W ten sposób skala i jakość zmian pod rządzami Wolfganga Schüssela zostanie umieszczona $\mathrm{w}$ odpowiedniej perspektywie.

W 2006 roku w „The Economist” ukazał się artykuł: Sound of Succes, który nawiązując do znanego, a dziejącego się w Austrii musicalu, Sounds of Music, w bardzo pozytywny sposób odnosił się do sytuacji gospodarczej Austrii. Jako najważniejszą przyczynę tego sukcesu autor artykułu podał położenie geograficzne, które pozwoliło Austrii na bardzo szybki rozwój poprzez inwestycje w Europie Środkowej i Wschodniej. Jednak taki rozwój nie byłby możliwy bez solidnych podstaw gospodarczych. Artykuł chwali instytucję Sozialpartnerschaft - nie do końca sformalizowanego forum komunikacji pomiędzy rządem, pracownikami, przedsiębiorstwami i przemysłem. To właśnie Sozialpartnerschaft odpowiada za warunki pracy robotników oraz to właśnie tam ustala się wysokość płac w poszczególnych branżach. Na kolejną pochwałę zasługują instytucje państwa dobrobytu, porównywalne do tych w krajach nordyckich ${ }^{8}$.

W ciągu pięciu dekad z zapóźnionego rolniczego kraju, który w okresie międzywojennym utrzymywał się wyłącznie dzięki angielskim i francuskim kredytom, Austria stała się jednym z najzamożniejszych państw nie tylko w Europie, ale i na świecie. Po trudnych latach powojennych $\mathrm{w}$ latach pięćdziesiątych $\mathrm{XX}$ wieku ukonstytuował się ponadpartyjny konsensus co do kierunku rozwoju kraju. Podstawą miała być gospodarka rynkowa z bardzo silnym elementem polityki społecznej i wpływu państwa. Austriackiemu państwu udało się znaleźć odpowiednią równowagę pomiędzy wspieraniem eksportu i inwestycji a utrzymaniem odpowiednio wysokiej stopy życiowej pracujących. Rozwój zabezpieczeń społecznych i polityka dążąca do jak najszerszego zatrudnienia pozwoliła osiągnąć wysoki poziom życia. Johannes Ditz, jeden z architektów późniejszej neoliberalnej przemiany i współpracownik Schüssela, określa ten model gospodarczy, który wykształcił się w alpejskiej re-

8 Sound of Succes, „,The Economist", http://www.economist.com/node/10128864. 
publice, jako „,austrokeynesizm9. Szybki rozwój gospodarczy z lat sześćdziesiątych i siedemdziesiątych został spożytkowany na powiększenie zakresu działania państwa i rozbudowanie systemu opieki społecznej. Kryzysy z połowy lat siedemdziesiątych oraz początku lat osiemdziesiątych rozwiązywano właśnie w oparciu o model Keynesa: zwiększając zatrudnienie $\mathrm{w}$ sektorze publicznym (zwłaszcza w państwowym przemyśle) oraz pobudzając popyt przez finansowe wsparcie rodzin.

Utrzymanie zatrudnienia oraz wzrostu gospodarczego odbyło się kosztem ogromnego wzrostu zadłużenia z 50 mld szylingów w 1970 roku do ponad 700 mld szylingów w roku 1988 oraz wzrostem obciążeń podatkowych z $34 \%$ do $41 \%$. Najpoważniejszym skutkiem prowadzenia austrokeynsowskiej polityki była utrata potencjału inwestycyjnego austriackich firm i spadek ich konkurencyjności wobec zagranicznych podmiotów. Dotowanie całych gałęzi gospodarki z zapomogi stało się potrzebą w połowie lat osiemdziesiątych, gdy okazało się, że państwowe firmy i przedsiębiorstwa zaczęły przynosić straty. Jednocześnie z rekordowego poziomu w 1980 roku bezrobocie wzrosło z $2 \%$ do ponad 5\% w 1987 roku.

Pierwszą jaskółką zwiastującą zmiany był nowy program ÖVP stworzony w 1987 roku przez m.in. Johannesa Ditza i Wolfganga Schüssela (wtedy pracownika Austriackiej Federacji Biznesu), pod socjaldemokratycznym kanclerzem Franzem Vranitzkim, następcą Bruno Kreisky'ego. Vranitzky starał się zbilansować budżet, by spowolnić wzrost deficytu i zadłużenia. Zamrożono wzrost płac $\mathrm{w}$ administracji publicznej oraz ograniczono dotacje dla samorządów. Obniżono też stawki wypłacanych emerytur dla osób decydujących się na szybsze na nią przejście. Jednakże rozbudowane państwo dobrobytu i jego instytucje cały czas powodowały, że nie dało się ograniczyć deficytu poniżej $5 \% \mathrm{PKB}^{10}$. Dalsze próby balansowania budżetu i wydatków państwa oparte były na zwolnieniach $w$ administracji publicznej. Po raz pierwszy dokonano prywatyzacji, by załatać dziury w budżecie. W 1993 roku zrefor-

9 J. Ditz, Economic Policies and Economic Change, w: The Schüssel Era in Austria, Contemprary Austrian Studies vol. 18, University of New Orleans Press, UNO-Press Innsbruck, New Orlean 2010, s 235. Podobnie nazywa ten system Christian Dieninger w: Die Umstrittene Wende Österreich 2000-2006, Böhlau Verlag, Wien 2013, s. 211.

10 Ch. Dieninger, Die Umstrittene..., s. 236. 
mowano państwowy holding przemysłowy Österreichische Industrieverwaltungs-AG (ÖIAG), by służył celom prywatyzacyjnym. Nowemu kierownictwu przedstawiono listę przedsiębiorstw do prywatyzacji oraz terminy do wykonania tego zadania. Na pierwszy ogień poszła austriacka telekomunikacja i poczta. Łącznie do 2000 roku na drodze ofert publicznych sprywatyzowano dziesięć państwowych przedsiębiorstw. Trzeba nadmienić jednak, że prywatyzacja w Austrii wyglądała zupełnie inaczej niż $\mathrm{w}$ Polsce. Spory pakiet akcji trafił do pracowników prywatyzowanych przedsiębiorstw. Jednocześnie wpływ polityków na proces prywatyzacji spowodował, że miała ona niepełny wymiar. Nie chcąc tracić państwowego wpływu bardzo często managerami w sprywatyzowanych przedsiębiorstwach zostawali byli posłowie (niektórzy specjalnie zrzekali się tej funkcji). Równocześnie rząd bardzo często zachowywał tzw. złotą akcję, czyli pakiet większościowy lub mniejszościowy akcji, który pozwalał wpływać na decyzje podejmowane $\mathrm{w}$ zarządzie sprywatyzowanych podmiotów. Celem takiej polityki było tworzenie nowych i utrzymanie istniejących miejsc pracy oraz zachowanie centrum decyzyjnego firm i spółek w Austrii ${ }^{11}$. Coraz większy wpływ konserwatystów w rządzie wielkiej koalicji (SPÖ oraz ÖVP) oraz wpływy z prywatyzacji pozwoliły na ograniczenie deficytu z 5\% do 1,7\% w 2000 roku, nie zatrzymało to jednak ogólnego wzrostu zadłużenia państwa w stosunku do $\mathrm{PKB}$, które na przełomie milleniów wyniosło 65,6\% austriackiego $\mathrm{PKB}^{12}$.

Kolejnym ważnym elementem nadchodzących zmian była polityka podatkowa. Chcąc pobudzić wzrost gospodarczy i poprawić warunki dla rozwoju przemysłu, handlu i innych gałęzi, wprowadzono dwie nowe ustawy podatkowe. Pierwszą jeszcze w 1989 roku, drugą zaś w 1994. Chociaż kanclerzem był socjalista Vranitzky, to obóz konserwatystów z Johannesem Ditzem oraz Wolfgangiem Schüsselem miał główny wpływ na nowe ustawy. Celem tych reform było podatkowe

11 F. Schneider, A. Belke, Privatization in Austria: Some Theoretical Reasons and First Results About the Privatization Proceeds, http://www.diw.de/sixcms/detail.php/41510 (dostęp: 3 marca 2016). Lista sprywatyzowanych przedsiębiorstw do 2000 roku: Austria Mikro Systeme, Austria Tabak, Austrian Airlines, Böhler Uddeholm, Flughafen Wien, ÖMV Aktiengesellschaft (Mineralöl), VA Technologie, Verbund EnergieVersorgung Niederösterreich (EVN), Voest Alpine Eisenbahnsysteme, Vorarlberger Kraftwerke (VKW).

12 J. Ditz, Economic Policies..., s. 235. 
odciążenie firm, które rozwijały się i przynosiły zyski. Zostawiając więcej pieniędzy w tych firmach, jednocześnie za pomocą kolejnych ulg promowano inwestycje $w$ innowacje i rozwój. Obniżono podatek CIT oraz zniesiono trzydziestoprocentowy podatek VAT od towarów luksusowych. Pierwsza reforma przyniosła obniżki obciążeń pracy (tzn. opodatkowania wynagrodzeń oraz przychodów), wraz z tą obniżką likwidowano również liczne odpisy czy wyłączenia z podatków. W ten sposób chciano uprościć system podatkowy, który przez swoje skomplikowanie umożliwiał stosowanie różnych kruczków prawnych, pozwalających ominąć uciążliwy obowiązek płacenia podatków. Zmniejszono progresje podatkową z astronomicznej, jak na polskie warunki, najwyższej stawki $62 \%$ do 50\%. Trzy kolejne stawki 51\%, 45\% oraz 39\% zastąpiono jedną wynoszącą 32\%.

CIT obniżono o 10\%, z 35\% do 25\%. Johannes Ditz, autor tej reformy podatkowej, chełpi się, że za jego sprawą przychody do budżetu państwa $\mathrm{z}$ tego tytułu wzrosły z 0,8 mld euro do 5,6 mld euro (przeliczając ówczesną wartość szylingów na wspólną europejską walutę). Ditz uważa, że ten szokujący wzrost przychodów jest skutkiem działania w praktyce tzw. krzywej Laffera, która pokazuje, że po przekroczeniu pewnego poziomu opodatkowania, przychody spadaja a po odpowiedniej obniżce podatków przychody wzrastają. Ta zdawkowa informacja może zaskakiwać. Dopiero wgłębienie się w temat pozwala na dostrzeżenie faktu, że za ten wzrost odpowiadało masowe przenoszenie się siedzib niemieckich firm, które działały w Europie Środkowo-Wschodniej, do Austrii, oraz gwałtowny wzrost inwestycji w tym regionie po upadku żelaznej kurtyny. Oczywiście niższa stawka CIT mogła zachęcać firmy do przenoszenia się do Austrii, jednak wydaje się, że to historyczny moment geopolitycznej zmiany był odpowiedzialny za wzrost austriackich przychodów do budżetu, a nie teoria Laffera ${ }^{13}$.

13 Philipp Ther uważa, że Wiedeń jest miastem, które najbardziej skorzystało nie tylko z upadku komunizmu, ale również z rozszerzenia Unii Europejskiej na wschód. Jego geograficzne położenie, silne powiązanie wykształconych elit w Austrii ze wszystkimi państwami byłego imperium Habsburgów oraz znajomość języków używanych w regionie pozwoliły Austrii na szybką ekspansję gospodarczą. Znacznie szybszą niż w przypadku Niemiec, które początkowo z rezerwą podchodziły do inwestycji w Europie Środkowo-Wschodniej. 
W drugiej fazie reform podatkowych zniesiono podatek od handlu oraz podatki od posiadanego kapitału. Jak widać, wiele zmian systemowych, które można by nazwać neoliberalnymi, wprowadzono jeszcze na długo przed rządami Wolfganga Schüssela. Sam Ditz wspomina, że podczas reform chodziło o całkowitą zmianę filozofii polityki podatkowej, którą Austria odziedziczyła po długich rządach Bruno Kreisky'ego. Ditz chciał zachęcić firmy do składania raportów podatkowych, w których wykazywałyby przychód i rozwój. Ciężar rozwoju PKB miał zostać przeniesiony z państwowych firm i dotacji na prywatny biznes.

Nie można mówić o austriackiej gospodarce nie wspominając o polityce budowania państwa dobrobytu (welfare state), które stało się cechą charakterystyczną alpejskiej republiki.

W austriackiej pamięci historycznej sukces budowy państwa dobrobytu jest bardzo silnie związany z pozytywną identyfikacją austriackich obywateli z własnym państwem. Jednocześnie powojenna dekada i związane z nią problemy, takie jak głód i niedożywienie oraz trud odbudowy, są jednoznacznie widziane jako negatywne skutki okupacji ${ }^{14}$. Według opinii publicznej zamożne państwo dobrobytu, jakim dziś jest Austria, powstało w 1955 roku wraz z podpisaniem traktatu o neutralności i opuszczeniu tego kraju przez sowieckich, amerykańskich, angielskich i francuskich żołnierzy. Jednakże początki austriackiego welfare state sięgają znacznie głębiej. Pierwsze kroki w budowie państwa dobrobytu zostały podjęte już w czasach monarchii austro-węgierskiej. Na przełomie 1884 i 1885 roku wprowadzono ograniczenie dziennego czasu pracy, w 1887 przymusowe ubezpieczenie od wypadków, a rok później ubezpieczenie zdrowotne. W 1906 roku pojawił się w pierwszy system emerytalny, chociaż był ograniczony i obejmował tylko zawody urzędnicze. Prospołeczne reformy rozwijano w czasie I Republiki po 1918 roku. Dopiero nadejście austrofaszystów do władzy w 1934 roku zahamowało ten proces. Przez perturbacje polityczne i wojenne zastój trwał aż do 1955 roku, w którym to przywrócono status quo sprzed faszystowskiego przewrotu. Wprowadzona w roku 1955 ustawa Allgemaines Sozialversicherungs Gesetz (ASVG) nie tylko przywracała poprzednie uprawnienia, ale także rozszerzała je na robotników i samozatrudnionych.

14 I. Rathkolb, The Paradoxical Republic, Berghahn, New York 2010, s. 217. 
Przywołana wcześniej uwaga Arnolda Schwarzeneggera, o tym, że pochodzi z socjalistycznego kraju, z pewnością bierze swoje źródło z polityki, jaką od 1966 roku prowadziła Socjalistyczna Partia Austrii (SPÖ), w szczególności zaś w latach kanclerstwa Bruno Kreisky'ego. To pod jego rządami polityka budowy społecznej gospodarki rynkowej w państwie dobrobytu osiągnęła swoje apogeum. Trudno wymienić wszystkie rozwiązania wprowadzone przez kolejne rządy Kreisky'ego. Spektrum świadczeń zostało poszerzone w każdym możliwym aspekcie. Początek zmian zwiastowało przeprowadzone w 1969 roku referendum dotyczące czterdziestogodzinnego tygodnia pracy. Później obniżono wiek emerytalny i jednocześnie zwiększono waloryzację emerytur. Państwo rozbudowało zasiłki dla bezrobotnych, wypłacało dodatki urlopowe i wprowadziło trzytygodniowy okres urlopowy (1971), opłacało urlopy macierzyńskie (1974), pojawiły się darmowe podręczniki szkolne i darmowe przejazdy dla uczniów (1972) itd. ${ }^{15}$

Wyróżniającym się elementem austriackiego modelu welfare state była polityka mająca na celu pełne zatrudnienie, zwłaszcza w czasach kryzysów gospodarczych (bezrobocie oscylujące w granicach 3\%, czasem zbliżające się nawet do $2 \%$ ). Na przełomie lat siedemdziesiątych i osiemdziesiątych austriackie welfare state osiągnęło szczyt swoich możliwości. Tak rozbudowane wsparcie socjalne i dotowanie zatrudnienia odbywało się kosztem szybko rosnącego zadłużenia. Następca Kreisky'ego Franz Vranitzky w latach 1986-1997 nie mógł już pozwolić budżetowi na tak rozbudowane rozdawnictwo, jednakże nie zdecydował się też na radykalne cięcia. Zmiany miały nadejść z kolejnym rządem.

\section{Neoliberalny przełom? Rządy kanclerza Wolfganga Schüssela}

W 2000 roku po wyborach parlamentarnych powstał nowy rząd składający się z partii ludowej ÖVP oraz wolnościowej FPÖ. Kanclerzem został Wolfgang Schüssel, a wicekanclerzem przedstawicielka liberałów Susanne Riess-Passer. Kontrowersyjny polityk Jörg Haider,

15 Ibidem, s. 224. 
który dotychczas przewodniczył FPÖ, specjalnie zrzekł się kierownictwa, by mogło dojść do umowy koalicyjnej. Niepisany obyczaj nakazywał, by przewodniczący partii pełnił funkcję wicekanclerza, co było nie do zaakceptowania przez wielu Austriaków oraz polityków ÖVP. Mieszanka konserwatystów oraz liberałów w rządzie wydawała się idealną podstawą do prowadzenia neoliberalnej polityki. Za pierwszy i najważniejszy cel uznano konsolidację budżetu oraz wydatków publicznych. Zamierzeniem obniżenia długu publicznego oraz deficytu budżetowego względem PKB było spełnienie kryteriów do przyjęcia wspólnej waluty. W tym przypadku neoliberalne idee nakładały się na warunki zewnętrzne, które warunkowały sposób prowadzenia polityki budżetowej. Jednakże Schüssel chciał iść o krok dalej i zaproponował kurs na politykę zerowego deficytu - null-Defizit. Kolejnym celem była zmiana w podejściu do już zaczętych prywatyzacji. Idąc za logiką wolnorynkowa, Schüssel planował wdrożyć program całkowitych prywatyzacji. Te państwowe przedsiębiorstwa, których część akcji ciągle znajdowała się $\mathrm{w}$ państwowych rękach, powinny zostać uwolnione z nieefektywnego gorsetu państwa. Kolejnym priorytetem rządu było wspieranie rozwoju rynku kapitałowego i wzmocnienie wiedeńskiej giełdy.

Aby spełnić wszystkie kryteria stawiane przed alpejską republiką przez Unię Europejską już w 1995 roku zaczęto wprowadzać politykę ograniczania długu publicznego. W 1995 roku wynosił on 66,5\% w stosunku do austriackiego PKB, zaś dziesięć lat później 61,7\%. Kryterium z Maastricht, które nakazuje utrzymywać poziom zadłużenia poniżej $60 \%$, zostało osiagnięte dopiero w ostatnim roku rządu konserwatystów i liberałów, czyli w roku 2006, z zadłużeniem na poziomie 59,1\% PKB.

Oczko w głowie nowego kanclerza, czyli polityka zerowego deficytu, okazało się niewypałem. Rząd starał się ograniczyć deficyt budżetowy nie mierząc środków na zamiary. Podwyższono podatki, zaczęto ograniczać programy socjalne oraz zwolniono ponad 6 tys. osób z administracji publicznej. W 2001 roku udało się wypracować lekką nadwyżkę budżetowa, jednak wielkie niezadowolenie społeczne i krytyczne uwagi ze strony FPÖ, które groziły zerwaniem koalicji, oraz bardzo słaby wzrost gospodarczy (na poziomie $0,6 \%$ ) doprowadziły do zmia- 
ny politycznego kursu. Jörg Haider krytykował swojego koalicjanta, że prowadzi swoją politykę kosztem zwykłego człowieka16.

Stojąc wobec oporu społeczeństwa i oporu koalicjantów, Schüssel musiał porzucić marzenia o zerowym deficycie i zmienił swoją retorykę. Nowym pomysłem był program "równania do cyklów koniunkturalnych” (Ausgleich ueber den Konjunkrurzyklus). Nowy program oznaczał częściowe oddanie pola keynesowskiemu myśleniu o gospodarce i państwie. Wzrost gospodarczy, który dla neoliberałów jest wyznacznikiem sukcesu i rozwoju, musiał nadal być podtrzymywany przez działanie i inwestycje państwa. Mimo wszystko deficyt budżetowy udało się utrzymać na niskich poziomach $(-0,5 \% \mathrm{w}$ roku 2002 oraz $-1,4 \% \mathrm{w}$ roku 2006).

Pomimo porażki programu zerowego deficytu Schüsselowi udało się znacząco ograniczyć wpływ państwa na gospodarkę. Po raz pierwszy od czasów Kreisky'ego udział państwa w wytwarzaniu PKB spadł poniżej 50\%, co oznaczało, że rozwój w coraz większej mierze oparty był na rozwoju prywatnego kapitału. Jak chwali się Johannes Ditz, udało się to osiągnąć bez podwyżki podatków. Jednakże nie wspomina, że ograniczenie wydatków państwa było spowodowane obniżeniem finansowania licznych gałęzi gospodarki. Zreformowano i zmniejszono administrację poprzez łączenie podmiotów (np. policji i żandarmerii), a nauka na austriackich uniwersytetach stała się płatna.

Najważniejszą reformą jednak miała być zmiana w systemie emerytalnym. Chcąc jednocześnie odpowiedzieć na problem starzejącego się społeczeństwa oraz chcąc utrzymać budżet i zadłużenie w ryzach, rząd postanowił przyjąć pakiet reform zmieniających charakter emerytur. W 2003 oraz 2004 roku dokonano licznych zmian. Miały one dotyczyć wszystkich ludzi, którzy w styczniu 2005 roku osiągnęliby wiek 50 lat. Wysokość składek wynosiła 22\% dla zatrudnionych na umowie o pracę, 17,5\% dla samozatrudnionych oraz $15 \%$ dla rolników. Wysokość emerytury miała wynosić 80\% wysokości zarobków, ale dopiero po przepracowaniu czterdziestu pięciu lat, wysokość emerytury miała być uzależniona od zarobków uzyskanych w całym tym okresie, a nie jak było wcześniej w ostatnich piętnastu latach pracy.

16 R. Kriechbaumer, F. Schausberger (red.), Die Umstrittene Wende Österreich 2000-2006, Böhlau Verlag, Wien 2013, s. 242-248. 
Przepracowanie czterdziestu pięciu lat uprawnia również do przejścia na wcześniejszą emeryturę (matki mogą wliczyć aż cztery lata spędzone na urlopach macierzyńskich i wychowawczych do liczby przepracowanych lat). Obniżono również wartości waloryzacji emerytur. Usunięto większość ulg dotyczących różnych grup społecznych i zawodowych, każdy obywatel miał otrzymać takie same uprawnienia i przywileje emerytalne. Zachowano jednak przywilej dla robotników pracujących w ciężkich warunkach, którzy mogą przechodzić na wcześniejszą emeryturę. Jednak mimo to sam proces przechodzenia na wcześniejszą emeryturę stał się dużo trudniejszy, a w niektórych przypadkach niemożliwy (np. po długich okresach bezrobocia). Zlikwidowano też wszystkie czynniki, które oprócz pracy powodowały wzrost wysokości wypłacanego świadczenia emerytalnego. Wiek emerytalny ustalono na 65 lat. Nie był to twardo określony wiek, na wcześniejszą emeryturę można było przejść już w wieku 62 lata, jednak należało się liczyć z drastyczną obniżką świadczeń emerytalnych. System premiował też późniejsze przechodzenie na emeryturę i wydłużenie czasu pracy. Chcąc zmodernizować sposób obsługi obywateli wprowadzono kolejną reformę w 2005 roku. Każdy z opłacających składki miał otrzymać swoje konto osobiste, na którym mógł sprawdzać stan swojej przyszłej emerytury. Obniżając wysokość emerytur i likwidując przywileje emerytalne, jak pisze polityk ÖVP, Johannes Ditz, udało się wprowadzić wiele niepopularnych decyzji, które mimo wszystko miały na celu dobrostan każdego obywatela. Jak twierdzi, zagwarantowano bezpieczeństwo systemu emerytalnego w dłuższej perspektywie, kosztem chwilowych niedogodności ${ }^{17}$.

Drugą w kolejności najważniejszą zmianą miało być usprawnienie prywatyzacji. Zreformowany w 1993 roku państwowy holding przemysłowy ÖIAG w 2000 roku był ciągle właścicielem większości fabryk i przedsiębiorstw państwowych. Co więcej, jego kondycja pomimo wcześniejszych częściowych prywatyzacji nie była najlepsza. Wszystkie podmioty będące pod zarządem ÖIAG generowały łącznie

17 H. Obinger, E. Tálos, Sozialstaat Österreich zwischen Kontinuität und Umbau, VS Verlag für Sozialwissenschaften, Wiesbaden 2006, s. 144. Zob. również: M. Preglau, Schussel and the Welfare State, University of New Orleans Press, UNO-Press Innsbruck, New Orlean 2010. s. 262-278. 
ok. 5 mld euro straty i holding musiał być ratowany co roku z budżetu państwa.

Priorytety kanclerza Schüssela były wybitnie neoliberalne. Pierwszym z nich było stworzenie jak największej wartości dla posiadaczy akcji, tzn. zwiększenie zamożności akcjonariuszy poprzez wypłacanie większych dywidend. Był to podstawowy cel prywatyzacji. Dopiero w następnej kolejności podkreślono potrzebę rozwiązania problemu zadłużenia ÖIAG. Na samym końcu zaś wspomniano kwestię bezpieczeństwa zatrudnionych. Odpowiednie przepisy miały amortyzować negatywne skutki zwolnień po prywatyzacji danego przedsiębiorstwa ${ }^{18}$.

W roku 2001 proces prywatyzacji nabrał prędkości. Zaczęto sprzedawać akcje instytucji, które były częściowo w austriackich rękach, np. lotniska w Wiedniu czy część akcji Austria Telekom. W dalszej kolejności sprzedano państwowy przemysł tytoniowy Austria Tabak oraz całość Print Media Austria odpowiadającej za znaczną część rynku wydawniczego w kraju. W 2004 roku tempo prywatyzacji zaczęło spadać i nie wszystkie instytucje udało się sprywatyzować w całości i wielokrotnie ÖIAG ciagle pozostawał częściowym udziałowcem. Poza pocztą w której ÖIAG ma ciągle większościowy pakiet akcji, nie istnieje już w Austrii żadne przedsiębiorstwo, które byłoby zarządzane wyłącznie przez ÖIAG. W 2006 roku, pod koniec rządów konserwatywno-liberalnej koalicji, cele reformy prywatyzacyjnej zostały osiągnięte. Jesienią 2006 roku okazało się, że ÖIAG nie jest zadłużony i wypracowuje relatywnie niewielką nadwyżkę w wysokości $250 \mathrm{mln}$ euro. Ten zysk jest jednak tymczasowy i oparty na sprzedaży kolejnych akcji, jest więc zyskiem z prywatyzacji. Większość austriackiego majątku została zakupiona przez kapitał niemiecki, brytyjski i włoski. Tylko niewielka część akcji znalazła nabywców w osobach austriackich akcjonariuszy, którzy po prostu nie dysponowali odpowiednim kapitałem.

Chociaż prywatyzacja odniosła sukces odciążając budżet państwa, to zrodziła też liczne negatywne komentarze. Najradykalniejszym głosem jest książka Klausa Grubelnika Der zweite Anschluss, której zasadniczą tezą jest stwierdzenie, że Niemcy krok po kroku wykupują Austrię i zyskują przemożny wpływ na austriacką gospodarkę, a przez

18 H. Auer, Neoliberalismus..., s. 215-218. 
to i na austriacką politykę. Lista sprywatyzowanych instytucji i przedsiębiorstw liczy kilkanaście stron ${ }^{19}$. Trzeba jednak zaznaczyć, że książka Grubelnika ma charakter publicystyczny, a nie naukowy. Przypomina ona swoim tonem historie i skandale z prasy bulwarowej. Niemniej jednak jest istotnym głosem w debacie dotyczącej prywatyzacji w Austrii.

Czas kanclerstwa Wolfganga Schüssela to również okres rozwoju austriackiego rynku kapitałowego. Wraz z kolejnymi prywatyzacjami wiedeńska giełda nabrała wiatru w żagle. Jak już napisano powyżej, prywatyzacja w Austrii bardzo często polegała na sprzedaży akcji danego przedsiębiorstwa czy instytucji. Centralną rolę w takiej prywatyzacji odgrywała właśnie giełda w Wiedniu. Może to zaskakiwać, że jedna z najstarszych giełd w Europie, której załamanie w maju 1873 roku doprowadziło do globalnego kryzysu, była tak nieznacząca i niedorozwinięta w XX wieku. Otwarcie na świat miało przyjść dopiero z początkiem XXI wieku. W 2001 roku Schüssel rozpoczął reformę rynku kapitałowego w alpejskiej republice. Oprócz wprowadzenia nowej legislacji określającej warunki działalności giełdy rozpoczęto również promocję tego parkietu za granicą. Kapitalizacja giełdowa rosła w astronomicznym tempie z 32 mld euro w 2002 roku do 146 mld euro cztery lata później. Właśnie na przykładzie austriackiej giełdy widać, że z neoliberalnych reform najbardziej korzysta rynek kapitałowy. Mając silne oparcie $\mathrm{w}$ zachodnim kapitale i jednocześnie czerpiąc zyski z otwarcia się na inwestycje w Europie Środkowo-Wschodniej, wiedeńska giełda stała się najważniejszym parkietem w regionie. Dopiero kryzys finansowy z 2008 roku i kryzys w strefie euro pozwolił warszawskiej giełdzie przejąć pałeczkę lidera. Rozwój wiedeńskiej giełdy był szybki, ale też i krótkotrwały, oparty jedynie na obrocie zyskami z prywatyzacji, które były jednorazowe. O ponownej utracie znaczenia wiedeńskiej giełdy świadczą głosy i plany przejęcia jej przez giełdę warszawską ${ }^{20}$.

Hannes Auer w swej pracy dotyczącej neoliberalizmu w Austrii przeanalizował trzy dziedziny polityki pod rządami Wolfganga Schüs-

19 K. Grubelnik, Der zweite Anschluss. Deutschlands griff nach Osterriechs Wirtschaft, Molden Verlag, Wien 2000. s. 292-304.

${ }^{20}$ Istniejąca od stuleci giełda wiedeńska szuka ratunku w Warszawie, http://biznes. $\mathrm{pl} /$ magazyny/finanse/istniejaca-od-stuleci-gielda-wiedenska-szuka-ratunku-w-warszawie/h482j (dostęp: 3 marca 2016). 
sela: gospodarkę, szkolnictwo oraz politykę zdrowotną. Działania rządu w latach 2000-2006 w gospodarce zostały przedstawione powyżej, dlatego warto pochylić się nad pozostałymi dwoma. Auer zaznacza, że początkowo w sferze deklaratywnej rząd Schüssela chciał dokonać neoliberalnej $\mathrm{w}$ duchu reformy służby zdrowia. Bardzo szybko jednak wycofał się z tych deklaracji. Mając problemy zarówno ze zmianą obowiązującego prawa, jak i protestami społeczeństwa, które okazało się przywiązane do swojej służby zdrowia, wycofano się z planowanych zmian. Dalej Auer wspomina o polityce wobec szkolnictwa. Poza wprowadzeniem czesnego za studiowanie, podkreśla on, że częściowe „urynkowienie” systemu szkolnictwa doprowadziło jedynie do oddemokratyzowania struktury szkół i uniwersytetów oraz przeniesienia części dotacji na szkolnictwo do sektora prywatnego (tj. do prywatnych szkół i uniwersytetów). Reformy te były jednak tak niepopularne, że zostały cofnięte już w 2008 roku. Auer przyznaje, że w polityce zdrowotnej i dotyczącej szkolnictwa neoliberalizmowi nie udało się zdobyć silnych przyczółków i zadomowić się. Wpływ neoliberalizmu na służbę zdrowia był żaden, a na szkolnictwo tymczasowy i powierzchowny. Wskazuje jednak, że rządowi konserwatywno-liberalnej koalicji udało się doprowadzić do zmiany paradygmatu prowadzenia polityki ${ }^{21}$. Chociaż następny rząd składający się już z tradycyjnej „czarno-czerwonej” (konserwatywno-socjaldemokratycznej) koalicji cofnął część reform, to $\mathrm{w}$ sferze gospodarczej neoliberalizm triumfował. Myślenie o upaństwawianiu przedsiębiorstw stało się nieuprawnionym przeżytkiem. Powrót do sposobów prowadzenia polityki z czasów Bruno Kreisky'ego wydaje się niemożliwy. Na znaczeniu tracą związki zawodowe i przede wszystkim smarowidło instytucjonalnych trybów austriackiego państwa, czyli Sozialpartnerschaft. Coraz więcej decyzji dotyczących gospodarki podejmowanych jest poza tą instytucją i jest ona zależna nie tylko od austriackich polityków, ale od licznych podmiotów prywatnych, korporacji i międzynarodowych organizacji. To przesunięcie można nazwać liberalnym, ale wynika też z zmieniających się struktur gospodarek narodowych w zglobalizowanym świecie.

${ }^{21}$ H. Auer, Neoliberalismus..., s. 236-238. 


\section{Podsumowanie}

Siedem lat kanclerstwa Wolfganga Schüssela to bez wątpienia czas triumfu neoliberalizmu. Chociaż pierwsze reformy w neoliberalnym duchu były wprowadzane przed 2000 rokiem, to były one inspirowane przez samego Schüssela albo jego współpracowników. Austria jest przykładem kraju, w którym neoliberalne polityki zostały wprowadzone relatywnie późno i w ograniczonym zakresie w porównaniu z innymi państwami europejskimi. Schemat przeszczepiania tych idei jest jednak podobny do polskiego przypadku. Grupa ludzi o mocno wyklarowanych neoliberalnych poglądach, będących pod silnym wpływem Miltona Friedmana i innych ekonomistów z chicagowskiej szkoły ekonomicznej, zdominowała na pewien okres scenę polityczną i zdobyła „rząd dusz”, zmieniając paradygmat prowadzenia polityki.

Jeśli porównać idee szerzone przez Friedmana łatwo zauważyć, że Schüssel w pełni odnalazł się jako neoliberał. Jego reformatorski zapał został jednak ograniczony przez bardzo silne w Austrii instytucje welfare state i przywiązanie obywateli do socjalnego państwa dobrobytu. Ani szkolnictwo, ani służba zdrowia nie doświadczyły neoliberalnej rewolucji. Nastąpiła ona natomiast w polityce społecznej i gospodarczej. Wydatki na politykę społeczną pod rządami Schüssela spadły do poziomu sprzed 1980 roku $^{22}$. W niektórych aspektach kanclerz poszedł nawet dalej niż deklarował, szczególnie podczas intensywnego okresu prywatyzacji, kiedy przestano przestrzegać zasady złotej akcji i wyprzedawano większościowy pakiet akcji spółek skarbu państwa.

Makroekonomiczne statystyki pokazują niezwykły rozwój i postęp Austrii podczas neoliberalnego reżimu. Znacząco udało się obniżyć zadłużenie państwa i zmniejszyć deficyt budżetowy. Pomimo problemów w pierwszych latach związanych z restrykcyjną polityką fiskalną, w późniejszym okresie udało się utrzymać wysokie tempo wzrostu gospodarczego. Również wiedeńska giełda przeżywała czas prosperity. Jeden $\mathrm{z}$ autorów neoliberalnych reform, Johannes Ditz,

\footnotetext{
22 O. Rathkolb, The Paradoxical Republic, s. 225.
} 
uważa, że Austria z nieatrakcyjnego, obciążonego wysokimi podatkami państwa socjalnego stała się nowoczesną i umiędzynarodowioną gospodarką ${ }^{23}$.

Jeśli jednak wyjść poza dane makroekonomiczne okaże się, że neoliberalny postęp nie przypadł w udziale niższym klasom społecznym i klasie średniej. Standard usług finansowych podniósł się znacząco, jednak jakość instytucjonalnych usług państwowych obniżyła się. Odsetek osób żyjących w ubóstwie wzrósł do 5\%, a osób zagrożonych ubóstwem do $7 \%$. Ponad $20 \%$ austriackiego społeczeństwa doświadczyło obniżenia ich standardu życiowego w latach 2000-200624. Małe i średnie przedsiębiorstwa nie odczuły poprawy swojej kondycji, gdyż stawki podatkowe ich dotyczące nie zostały obniżone.

Trzeba również spojrzeć na rządy konserwatywno-liberalnej koalicji z szerszej perspektywy. Większość pozytywnych zmian w austriackiej gospodarce można przypisać zmieniającej się na korzyść Austrii sytuacji geopolitycznej. Upadek żelaznej kurtyny oraz rozszerzenie Unii Europejskiej na wschód pozwoliły odbudować kontakty i powiązania, jakie Austria miała ze swoimi sąsiadami od czasów habsburskich. Austria zaczęła wykorzystywać swoją historyczną szansę jeszcze przed rządami Schüssela, który kontynuował politykę gospodarczego otwarcia się na Europę Środkowo-Wschodnią. Co więcej, należy uznać, że za znaczną część wzrostu gospodarczego Austrii w omawianym okresie odpowiadało właśnie owo otwarcie się na wschód, a niekoniecznie neoliberalne reformy.

Zyski $\mathrm{z}$ tego otwarcia $\mathrm{w}$ największym stopniu dotyczyły rynku kapitałowego i inwestorów, w mniejszym zaś ogółu austriackiej populacji. Wiedeń rozwijał się bardzo szybko, stając się czwartym najdroższym miastem $\mathrm{w}$ UE, tego samego nie można jednak powiedzieć o austriackiej prowincji. Alpejska republika doświadczyła wzrostu nierówności społecznej mierzonej indeksem GINI z 26 punktów do ponad 29.

23 J. Ditz, Economic Policies..., s. 261.

24 M. Preglau, Schussel and the Welfare State, The Schüssel Era in Austria, Contemprary Austrian Studies vol. 18, University of New Orleans Press, UNO-Press Innsbruck, New Orlean 2010, s. 276. 
Co zostało z neoliberalizmu w Austrii? Pod koniec 2006 roku zawiązała się koalicja SPÖ oraz ÖVP, w której ścierały się neoliberalne poglądy konserwatystów z prospołecznymi propozycjami socjaldemokratów. Polityczny pat doprowadził do wcześniejszych wyborów w 2008 roku. Był to jednak rok, w którym rozpoczął się kryzys finansowy i gospodarczy mocno podcinający skrzydła neoliberalnym ideom. Okazało się, że umiędzynarodowiona austriacka gospodarka stała się również mniej odporna na wstrząsy z zewnątrz. Gospodarka kurczyła się w tempie prawie $2 \%$ w skali roku, a zadłużenie wzrosło do $85 \%$ PKB, niosąc zagrożenie załamania ${ }^{25}$. Większość fiskalnych sukcesów neoliberalnej polityki została utracona $\mathrm{w}$ latach kryzysu. Utrata zaufania do neoliberalnych idei oraz powolny powrót do „tradycyjnej” socjalnej polityki w Austrii oznacza kolejną zmianę paradygmatu.

Choć intensywny, flirt alpejskiej republiki z neoliberalizmem trwał relatywnie krótko, a w dłuższej perspektywie skala jego oddziaływania okazała się ograniczona. Czy można zatem mówić o neoliberalnym przełomie w Austrii? Jak twierdzą autorzy największej pracy dotyczącej rządów Wolfganga Schüssela, jest umstritten, dyskusyjny ${ }^{26}$. W austriackiej polityce jest zbyt wiele ciągłości, a z perspektywy czasu przełom okazał się być krótkotrwały.

W 1996 roku jednym z haseł wyborczych Jörga Haidera było Wien darf nicht Chicago werden - Wiedeń nie może stać się Chicago. Populistycznemu politykowi chodziło o wpływ zagranicznych gangów i mafii w Chicago i użył tego stwierdzenia w kontekście coraz liczniej napływających do Austrii imigrantów z Europy Środkowo-Wschodniej oraz z Bałkanów. Myślę jednak, że można również to wyborcze hasło zastosować do próby wprowadzenia neoliberalnych idei chicagowskiej szkoły ekonomicznej w Austrii.

25 Pozytywne opinie o gospodarce Austrii zmieniły się w niepokój: Austria is fast becoming Europe's latest debt nightmare, The Telegraph, http://www.telegraph.co.uk/finance/ comment/jeremy-warner/11455671/Austria-is-fast-becoming-Europes-latest-debt-nightmare.html (dostęp: 2 marca 2012).

${ }^{26}$ R. Kriechbaumer, F. Schausberger (red.), Die Umstrittene... 


\begin{abstract}
Vienna Cannot Be like Chicago. Neoliberalism and Wolfgang Schüssel's Rule in Austria in 2000-2006

This article focuses on the impact of liberal ideas on Austrian politics. Particular attention is devoted to the conservative-liberal coalition lead by Chancellor Wolfgang Schüssel, who ruled in 2000-2006. The author presents the sources of the Austrian Chancellor's ideological inspirations and confronts the ideas declared by him and his coalition with reality. Schüssel's rule is described from a broader perspective in order to answer the question of whether the time of the neoliberal "breakthrough" was indeed a breakthrough, and how much of that has been left in Austrian politics?
\end{abstract}

